\title{
Policing the pandemic: the legitimacy of the police and the potential for civil unrest; a personal commentary
}

\author{
David B. Lewis ${ }^{1}$ B.A.(Hons) M.Ed. FCIPD FRSA M. Inst. L.M. \\ The London Policing College
}

\section{Introduction}

The 'Policing the Pandemic' seminar series hosted online by the London Policing College and the International Police Association in November 2020 raised important issues for the immediate security of the state. These included a concern reported by delegates following experiences with members of the public by police members in several different countries during the COVID-19 pandemic. These anecdotal reports raised the suggestion that the legitimacy of the formalised policing function in the face of unpopular political imposition may be increasingly at issue. This brief commentary outlines the potential for civil disorder that might take place if the legitimacy of the police is questioned to a point beyond civil disobedience on a major scale, and suggests the need for the police to prepare for outbreaks of major disorder in $2021 / 2022$.

\section{Historical perspective}

Civil disobedience in times of crisis has a long memory. The 'Black Lives Matter' campaign tells us this amongst much else that it highlights. But organised civil disobedience in the UK travels back to Wat Tyler and the Peasant's Revolt of 1381, a written description of which has chilling resonance today:

The revolt had various causes, including the socio-economic and political tensions generated by the Black Death pandemic in the 1340s, the high taxes ... . and instability within the local leadership of London. The final trigger for therevolt wasthe ... attempts to collect ... taxes which ended in a violent confrontation, which rapidly spread across the south-east of the country. ${ }^{2}$

Just history? Perhaps. But as George Santayana reminded us way back in 1905, 'Those who cannot remember the past are condemned to repeat it.'. ${ }^{\text {The }}$ The police need only cast their minds back a few years to the 'Troubles' of Northern Ireland and the bitter struggles that led to over 3,60o deaths, 300 of them police officers. ${ }^{4}$ In the face of today's tensions, we should be mindful of Ulster.

\section{The conditions of revolt}

What are the conditions that need to be in place for the police to be able to predict outbreaks of civil disorder? Firstly, it is necessary to note the difference between civil disobedience and civil disorder.

Civil disobedience is the active, actioned, refusal of a citizen to obey certain laws, demands, orders, or commands of a government. By some definitions, civil disobedience has to be non-violent to be called 'civil'. Hence, civil disobedience is sometimes equated with peaceful protests or non-violent resistance. ${ }^{5}$ 
Civil disorder, also known as civil disturbance or civil unrest, is an activity arising from a mass act of civil disobedience (such as a demonstration, riot, or strike) in which the participants become hostile towards authority, and authorities incur difficulties in maintaining public safety and order. ${ }^{6}$

Analysing past civil conflicts in the UK and elsewhere suggests the following are the usual pre-conditions:

- A collective sense of grievance, often political, or a convergence of multiple grievances (commodity or service shortage, hardship from strikes, civil or other warfare)

- Perceived economic disparity between groups in society

- Existing social discord, either temporary, caused by events occurring, or more permanent discord caused by underlying issues of dominance, oppression, or injustice

- Polarised political, social, or religious beliefs and dogma

- Continuous flashpoints of interaction(s) between authority and the discontented.

Thinking of Wat Tyler's revolt and these conditions, what do we have today?

- Socio-economic tensions generated by a pandemic (perceived unfairness between 'haves' and 'have nots', salaried employees and low paid workers, 'north' and 'south', 'leaves' and 'remains', 'BAME' and 'white', 'pro-vaccination' and 'no vaccination' affecting the effectiveness of herd immunity)

- A sense of grievance against perceived political incompetence in the handling of the pandemic by politicians

- Instability within the leadership in London

- The imposition and attempted collection of (higher) taxes. (Predicted to come).

Add to the 'Peasant's Revolt' list of pre-conditions the following current conditions in UK society:

- Racial tension fanned by intense social media exchange and perceptions of police bias

- An increased polarisation between sections of the community

- Political unrest caused by popular movements such as 'Extinction Rebellion' and 'Black Lives Matter'

- The perception of unfairness and injustice arising out of the pandemic (economic, social, and medical, based on geography, ethnicity, and 'privileged status')

- Dissonance between local and national government

- An ongoing ideological war with Islamic State and the possibility of dissatisfaction with the government in dealing with it

- The fear of negative outcomes arising from the engagement in an ongoing 'cyberwar' with enemy states

- The fear of negative outcomes from a migration 'war' should the global pandemic lead to mass migration scenarios

- 'Fake news' and the spread of mass disinformation.

This would appear to suggest we are moving towards a 'perfect storm' situation, the flashpoint of which could reasonably be predicted to occur when the tax imposition to pay for the funding of the pandemic is imposed, where, and if, the above conditions are still operating. A secondary and earlier flashpoint could reasonably be expected to occur at some stage following the finalisation of the Brexit trade deal negotiations, particularly in Northern Ireland.

\section{The expectation}

Tindall and Bates tell us that 'civil disobedience can be active or passive, direct or indirect. An individual can either actively commit a prohibited act or passively refuse to conform to a prescribed action'. 7 We are already witnessing both passive and active disobedience in terms of COVID-19 compliance - direct action, such as that taken by the Mayor of Manchester, and demonstrations in London against COVID-19 restrictions. And in the seminar on 'Policing 
the Pandemic', several reports from delegates and speakers showed things were moving into a phase of increasingly random criminal damage against public buildings. This has been particularly prevalent in Sweden, but has also occurred in the Netherlands, Belgium and Germany where increasing anti-lockdown resistance was also noted.

It is reasonable to assume in the UK situation that the first stage will be an increasing refusal by individuals to conform to the prescribed actions of COVID-19 prevention compliance. This could be followed by an increased enforcement regime, leading to increased conflict with the police and other authorities. The next stage would see civil disobedience and protest, demonstrations, wanton damage, and increases in disharmony within families and communities. The final stage would be active attacks on the state structures by organised resistance following a convergence of a united cause: the imposition of increased taxation on an already stretched individual economic situation.

\section{Conclusions}

It could be argued that the UK has moved through the first stages and is a tinderbox waiting for a flashpoint. The requirement therefore is threefold:

- To prepare the (now relatively inexperienced in civil disturbance) 'rank and file' policing personnel of the UK for increasing refusal to comply with the law, leading to civil disorder of a large scale sometime during 2021-2022

- To prepare the officials of state bodies psychologically and practically to cope with a sustained period of unrest with outbreaks of violent civil disorder

- To keep a national surveillance on the assumption of the policing function by localised 'vigilantes' or other 'assumed guardian' groups.

With judicious governance and a sensitive policing response the 'worst case scenario' may be avoided, but, as we have witnessed, 'worst case' scenarios have a habit of manifesting themselves in times of global crisis.

\section{Notes}

${ }^{1}$ D.B. Lewis served with National Police Training on secondment and was formerly the Head of Training at the Police Probationer Training Centre, Aykley Heads, Durham. He has delivered training and education interventions across the world, including South Africa, Germany, the USA, Hong Kong, Hungary, Iceland, Spain, Abu Dhabi, Turkey, and India. He led five youth justice delegations to China for the British Council and was a founding director of a youth conflict resolution organization, 'This Way Up Mediation'. He is currently an associate with the London Policing College and has recently completed work on both the "English in Policing' degree programme for the Police Academy of Cambodia and the Degree Holders Direct Entry Detective Training Programme for the Metropolitan Police. davidlewis@brynstowe.co.uk

2 Dunn, Alastair (2002). The Great Rising of 1381: The Peasants' Revolt and England's Failed Revolution. Stroud, UK: Tempus.

3 Santayana, G. (1905). The Life of Reason: The Phases of Human Progress. New York: Charles Scrivner and Sons, p. 284.

${ }^{4}$ bbc.co.uk/history 'Lost Lives' screened BBC2 7th March 2020.

${ }^{5}$ Morreall, J. (1976). 'The justifiability of violent civil disobedience', Canadian Journal of Philosophy, 6 (1): 35-47.

${ }^{6}$ United States Army. (2018). 'Field Manual No. 19-15: Civil Disturbances' (PDF) available at:

7 Tindall, D.B. \& Bates, K.L. (2008). In Encyclopaedia of Violence, Peace, \& Conflict (Second Edition).: Cambridge, MA: Academic Press, pp. 2224-2244. 